\title{
The potential of soil seed banks of a eucalypt wetland forest to aid restoration
}

\author{
J. Greet ${ }^{A, B}$ \\ VIC 3121, Australia \\ ${ }^{B}$ Corresponding author. Email: greetj@unimelb.edu.au
}

${ }^{A}$ School of Ecosystem and Forest Sciences, The University of Melbourne, 500 Yarra Bld, Richmond,

\begin{abstract}
Soil seed banks can play an important role in the regeneration of wetland vegetation. However, their potential role in the restoration of degraded wetland forests is less certain.

I surveyed the soil seed bank and extant floras of four sites across a eucalypt wetland forest of variable vegetation condition. At each site, the extant vegetation was surveyed within two $5 \mathrm{~m} \times 5 \mathrm{~m}$ quadrats, each from which 5 composite soil seed bank samples were collected.
\end{abstract}

Across the four sites, 57 (including 18 exotic) species were identified in the extant vegetation, while from the seed bank samples 6379 seedlings emerged from 80 taxa, 33 of which were exotic species. The soil seed bank was dominated by native and exotic monocots, and contained very few seeds of wetland tree or shrub species. Overall, the similarity between the extant and seed bank floras was very low ( 24\%).

Soil seed banks are likely to be of limited use in the restoration of degraded wetland forests, because the dominant species in such systems-woody and clonal plants-are typically absent from the soil seed bank. Wetland soil seed banks may contribute to the maintenance and diversity of understorey vegetation, however, they may also act as a source of exotic plant invasions, particularly when a wetland is degraded.

Keywords: Exotic plant invasion, soil seed bank, swamp forest, vegetation cycling, wetland restoration

Running head: Soil seed banks and eucalypt wetland forest restoration

\section{Introduction}

Soil seed banks confer resilience to wetland plant communities by allowing species-rich communities to persist during dry times and to recover rapidly following re-wetting (Brock et al. 2003; Capon \& Brock 2006). Soil seed banks also play an important role in the cycling of wetland vegetation during hydrological fluctuations (van der Valk \& Davis 1978; Brock \& Casanova 1997) and may support geomorphic recovery of degraded riparian zones through vegetation regeneration (O'Donnell et al. 2016). Nonetheless, studies that have considered the potential role of soil seed banks in wetland restoration have reached mixed conclusions. While some studies of wetlands have reported diverse seed bank floras appropriate for aiding restoration activities (Richter \& Stromberg 2005; Nishihiro et al. 2006; James et al. 2007; Li et al. 2008; Baldwin et al. 2010; Tererai et al. 2015), other studies have 
found seed banks lacking in target species for restoration (Middleton 2003; Lu et al. 2010; Kettenring \& Galatowitsch 2011). Conversely, other studies have suggested that the restoration of degraded environments, including wetlands, may be hampered by soil seed banks due to the prevalence of exotic plant propagules (Williams et al. 2008; Eldridge \& Lunt 2010).

It has been suggested that seed banks are important for the development of some components of the vegetation, but not others (Boedeltje et al. 2003). Indeed, woody wetland plant species are often poorly represented in the soil seed bank and reliant on alternative means of regeneration (Middleton 2003); the potential of the soil seed bank to contribute to the restoration of herbaceous vegetation may be greater (Boudell \& Stromberg 2008; O'Donnell et al. 2016). Understanding the similarity of species composition between the seed bank and extant vegetation (which for wetlands can vary greatly $\sim 20-80 \%$ ), can provide insights into the role of the seed bank in vegetation dynamics at a site, and thus its potential role in restoration (Hopfensperger 2007).

The purpose of the current study was to assess the utility of the soil seed bank for the restoration of eucalypt wetland forests of critical importance. These wetland forests, home to two critically endangered arboreal fauna, are in demonstrable decline and the target of considerable restoration efforts. With hydrological works planned aimed at naturalising water regimes and restoring forest habitat (through both improved condition of existing forests and promoting regeneration), the potential role of the soil seed bank to facilitate wetland forest regeneration required assessment. Accordingly, this study sought to answer: what was the composition of the soil seed bank in relation to the (1) extant vegetation? And (2) in relation to extant vegetation condition? And hence, what was the potential role of the soil seed bank in the maintenance and restoration of these critically important wetland forests?

\section{Methods}

\section{Study area}

This study focused on the wetland forests of the Yellingbo Nature Conservation Reserve, which is located $\sim 50 \mathrm{~km}$ east of Melbourne, SE Australia (Fig. 1). The reserve was gazetted in 1965 to protect the helmeted honeyeater (Lichenostomus melanops cassidix), and consists of narrow sections of remnant riparian forest (bounded by cleared agricultural land) along parts of several creeks. As well as the critically endangered helmeted honeyeater, the reserve also supports a genetically distinct and only known lowland population of the critically endangered Leadbeater's possum (Gymnobelideus leadbeateri) (Harley et al. 2005). Both these arboreal fauna species are strongly associated with Eucalyptus camphora (mountain swamp gum) forest/woodland and associated shrub thickets, which predominate in the wetter areas of the reserve adjacent to the Cockatoo and Macclesfield Creeks. These wetland forests comprise an understorey rich in sedges, are seasonally to near permanently inundated/waterlogged (Pearce \& Minchin 2001) and are collectively known as the 'Cockatoo Swamp'. This 'sedge-rich E. camphora swamp community' is threatened by extensive tree and shrub dieback and a lack of woody plant regeneration (Turner 2003), probably because of the result of hydrological alteration (with some riparian areas currently disconnected from the creeks by levees, and others suffering from prolonged waterlogging) (Greet 2015).

\section{Sampling design}

I surveyed the extant vegetation and soil seed bank at four sites across the Yellingbo Nature Conservation Reserve (Fig. 1). These sites were all within mature E. camphora swamp 
forest/woodland and were selected so that they were spatially distributed across the Cockatoo Swamp, and represented a range of overstorey and understorey vegetation conditions. One site was established on the Macclesfield Creek floodplain (Site MC) in an area with healthy overstorey and intact native understorey. The other three sites, CC, DA and PL, were located on the Cockatoo Creek floodplain. Site CC was semi-cleared with an understorey heavily invaded by exotics (with Holcus lanatus and Ranunculus repens particularly abundant). Site DA was in an area subject to prolonged waterlogging with dieback affected trees and shrubs yet an intact understorey. Site PL was established in an area with healthy overstorey, but moderately disturbed understorey vegetation. Thus, two of the four sites had healthy overstorey (MC and PL), and two sites had intact understorey (MC and DA).

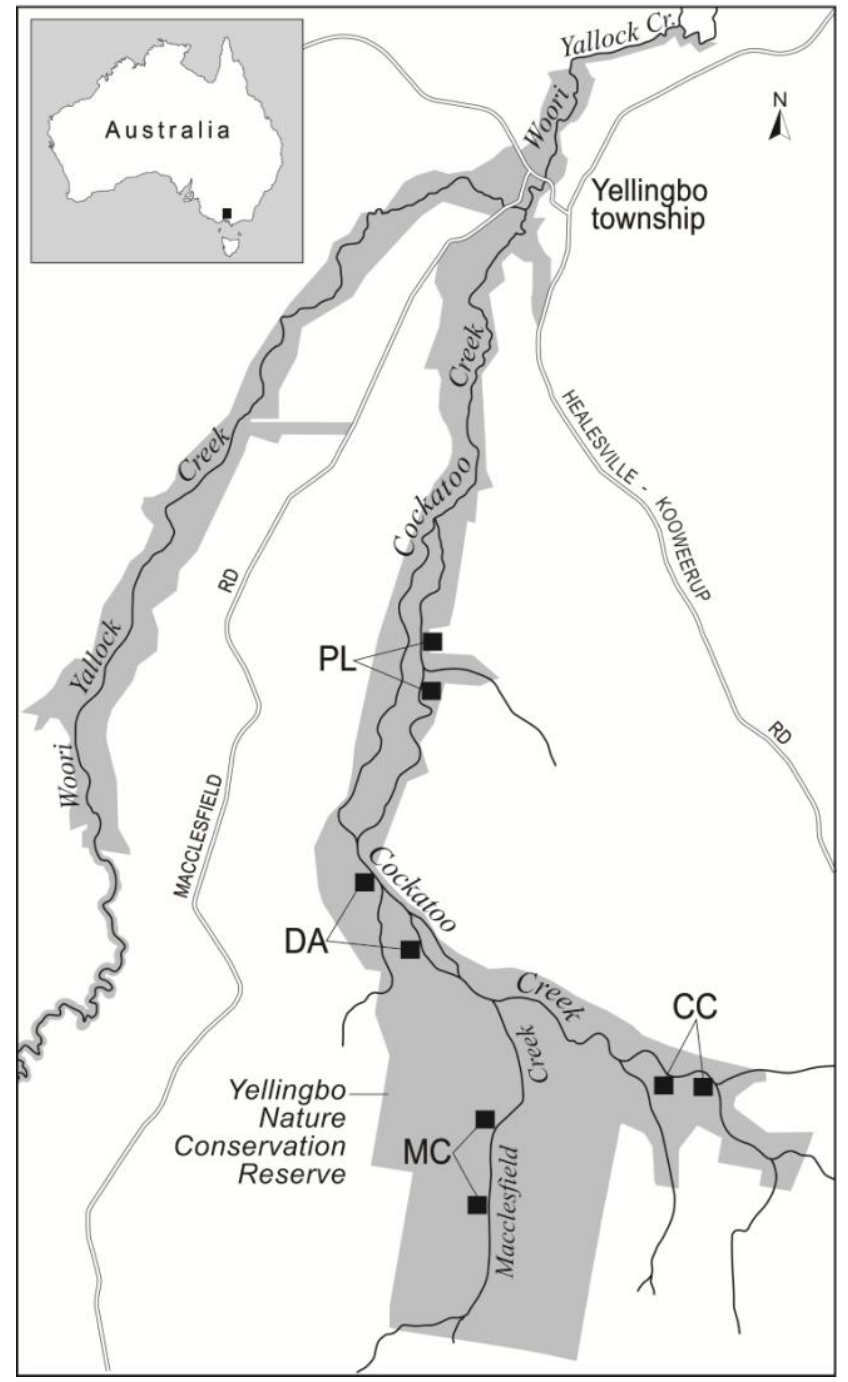

Fig. 1. Study site locations within the Yellingbo Nature Conservation Reserve where the extant vegetation and soil seed bank were surveyed. Labels indicate different sites, black squares indicate survey locations.

\section{Sampling}

I surveyed the extant vegetation and collected soil seed bank samples in August (late winter) 2012. Firstly, two $5 \mathrm{~m} \times 5 \mathrm{~m}$ quadrats were randomly established at each site. For each quadrat, the estimated projective foliage cover of all extant plant species identified was recorded (to the nearest $5 \%$ ), and five randomly located soil seed bank samples were collected. Each seed bank sample comprised five replicate cores taken to a depth of $5 \mathrm{~cm}$ using a soil augur of $5 \mathrm{~cm}$ diameter. Thus, 40 
composite seed bank samples ( 4 sites $\times 2$ quadrats $\times 5$ samples) were collected. Soil seed bank samples were dried and their composition determined using the seedling emergence (or 'grow out') method (Poiani \& Johnson 1988; Gross 1990). Specifically, dried samples were spread evenly (to 5 $\mathrm{mm}$ depth) over seedling trays filled with moistened sterile seed raising media. Control trays with media but without seed bank material were used to monitor for contamination (none was observed). Trays were placed randomly within a glasshouse wherein temperatures were maintained between $16-18^{\circ} \mathrm{C}$ at night and $23-25^{\circ} \mathrm{C}$ during the day, and samples kept moist via mist irrigationconditions considered appropriate for the germination of the vast majority of Australian wetland plant species (Brock et al. 1994; Casanova \& Brock 2000). Emergent seedlings were identified to species level and removed. When necessary, seedlings were potted up to facilitate flowering and identification. Samples were discarded after no further germinants were observable ( $\sim-6$ months).

\section{Data analysis}

For analyses, all taxa were identified to species level, except in the case of two grass seed bank taxa. For the seed bank taxa, numbers of taxa, as well as seedling abundances were determined for taxa grouped according to origin (native or exotic), growth form (monocot, forb, or woody), and life-span (annual/biennial or perennial). Species recorded in the extant vegetation were grouped similarly. For the seed bank taxa, differences in species richness and seedling abundances for the various plant groupings were assessed using ANOVAs with Site as a fixed factor and Quadrat as a random factor nested within Site. For significant Site differences, differences between Site means were assessed using a Tukey's HSD test. For all univariate tests, residuals were examined to ensure they fulfilled the assumptions of normality and homogeneity of variance, and data square-root transformed where necessary, i.e. for all seedling abundance analyses.

Two-dimensional non-metric multidimensional scaling (NMDS; Kruskal \& Wish 1978), permutational MANOVA (PERMANOVA; Anderson 2001), hierarchical cluster analyses, and similarity percentage (SIMPER; Clarke \& Gorley 2001) analyses were conducted using the Bray-Curtis dissimilarity measure in Primer v6 to examine assemblage-level differences between the extant and seed bank floras. For the PERMANOVA, Flora type (extant or seed bank) and Site were treated as fixed factors, with Quadrat nested within Site included as a random factor. Indicator value analysis was conducted using the indicspecies package in $\mathrm{R}$ to determine species associations with either the extant and seed bank floras (De Caceres \& Legendre 2009). All species were included and assemblage data transformed to presence/absence for all multivariate analyses.

\section{Results}

\section{Extant vegetation}

Fifty-seven species were recorded in the extant vegetation across the four sites, of which more than two-thirds (39) were native (Table 1). Almost all native species were perennials, while half of the 18 exotic species were annual or biennial species. The surveyed vegetation included 9 woody species (of which the blackberry, Rubus anglocandicans*, was the only exotic; N.B. asterisks are used hereafter to denote exotic species). E. camphora and Carex appressa were the most frequently observed species, occurring in 7 out of the 8 quadrats, with Phragmites australis, Melaleuca squarrosa, and Baumea rubiginosa also common (see Appendix 1 for full list of surveyed species). 


\section{Seed bank flora}

A total of 6,379 seedlings emerged from the soil seed bank samples. These were from 80 different taxa, including 45 native and 33 exotic species (Table 1). The four most common species were all Juncus species: J. bufonius (963 seedlings), J. bulbosus* (742), J. articulatus* (666), and J. planifolius (647). Together these four species accounted for almost half of all seedlings - and none were recorded in the extant vegetation. Native trees and shrubs accounted for only 28 seedlings representing six species; no $E$. camphora or $M$. squarrosa seedlings emerged from the seed bank samples. Most seed bank taxa were represented by only a relatively small number of seeds (see Appendix 2 for full list of seed bank taxa).

Table 1. Total numbers of taxa that were surveyed in the extant vegetation and that emerged from seed bank samples collected across all four sites.

\begin{tabular}{lrrrrrr}
\hline & \multicolumn{3}{c}{ Extant vegetation } & \multicolumn{3}{c}{ Seed bank flora } \\
& native & exotic & TOTAL & native & exotic & TOTAL \\
\hline Species richness & 39 & 18 & $\mathbf{5 7}$ & 45 & 33 & $\mathbf{8 0}$ \\
annuals/biennials & 2 & 9 & $\mathbf{1 1}$ & 7 & 17 & $\mathbf{2 4}$ \\
perennials & 37 & 9 & $\mathbf{4 6}$ & 38 & 16 & $\mathbf{5 3}$ \\
monocots & 18 & 3 & $\mathbf{2 1}$ & 19 & 9 & $\mathbf{2 9}$ \\
forbs & 12 & 14 & $\mathbf{2 6}$ & 20 & 23 & $\mathbf{4 3}$ \\
woody & 8 & 1 & $\mathbf{9}$ & 6 & 1 & $\mathbf{7}$ \\
\hline
\end{tabular}

\section{Similarity between the extant and seed bank floras}

Twenty-four species, including 3 exotic and 2 annual species, were found solely in the extant vegetation (and not in the seed bank). Conversely, 47 species, including 18 exotic and 15 annual/biennial species, were found solely in the seed bank. Fourteen species from a range of growth forms were significantly associated with the extant vegetation, including three woody species (Table 2). Six species were significantly associated with the seed bank flora, five of which were monocots, none were woody and two were exotic (Table 2). There were no species associated with both. Overall, the similarity between the extant and seed bank floras was very low (average similarity $\sim 24 \%$ across all sites). Correspondingly, the ordination separated the extant vegetation and seed bank data, and this difference between the extant and seed bank floras was significant; $P=$ 0.009 . While hierarchical cluster analyses grouped most of the extant vegetation data and seed bank sample data separately in two large clusters, it grouped both the extant and seed bank floras of Site CC in a third separate cluster (at the $25 \%$ similarity level; Fig. 2).

Table 2. Species significantly associated with either the extant or seed bank floras determined by indicator species analyses. Species characteristics presented are origin (native or exotic), growth form (monocot, forb or woody), and lifespan (a - annual, $p$ - perennial). Specificity = affinity to a flora type, i.e. a specificity of 1 means that species was solely found in that flora type. Frequency = proportion of samples of that flora type in which that species was present. Stat = test statistic. $p=$ significance level.

\begin{tabular}{llllllll}
\hline Species & Origin & $\begin{array}{l}\text { Growth } \\
\text { form }\end{array}$ & $\begin{array}{l}\text { Life- } \\
\text { span }\end{array}$ & Specificity & Frequency & Stat & $p$ \\
\hline \multicolumn{2}{l}{ Species associated with the extant vegetation } & & & & & \\
Eucalyptus camphora & native & woody & $\mathrm{p}$ & 1 & 0.875 & 0.935 & $\mathbf{0 . 0 0 1}$ \\
Phragmites australis & native & monocot & $\mathrm{p}$ & 1 & 0.625 & 0.791 & $\mathbf{0 . 0 0 1}$ \\
Melaleuca squarrosa & native & woody & $\mathrm{p}$ & 1 & 0.5 & 0.707 & $\mathbf{0 . 0 0 2}$ \\
Baumea rubiginosa & native & monocot & $\mathrm{p}$ & 1 & 0.5 & 0.707 & $\mathbf{0 . 0 0 1}$ \\
Persicaria praetermissa & native & forb & $\mathrm{p}$ & 1 & 0.375 & 0.612 & $\mathbf{0 . 0 0 3}$ \\
\hline
\end{tabular}




\begin{tabular}{llllllll}
\hline Tetrarrhena juncea & native & monocot & $\mathrm{p}$ & 1 & 0.375 & 0.612 & $\mathbf{0 . 0 0 6}$ \\
Gahnia radula & native & monocot & $\mathrm{p}$ & 1 & 0.375 & 0.612 & $\mathbf{0 . 0 0 6}$ \\
Schoenus lepidosperma & native & monocot & $\mathrm{p}$ & 1 & 0.375 & 0.612 & $\mathbf{0 . 0 0 5}$ \\
Galium aparine & exotic & forb & $\mathrm{a}$ & 0.94 & 0.375 & 0.593 & $\mathbf{0 . 0 1}$ \\
Prunella vulgaris & exotic & forb & $\mathrm{p}$ & 0.88 & 0.375 & 0.575 & $\mathbf{0 . 0 3 2}$ \\
Gonocarpus humilis & native & forb & $\mathrm{p}$ & 0.88 & 0.375 & 0.575 & $\mathbf{0 . 0 2 6}$ \\
Coprosma quadrifida & native & woody & $\mathrm{p}$ & 1 & 0.25 & 0.5 & $\mathbf{0 . 0 3}$ \\
Triglochin procera & native & forb & $\mathrm{p}$ & 1 & 0.25 & 0.5 & $\mathbf{0 . 0 2 4}$ \\
Ranunculus inundatus & native & forb & $\mathrm{p}$ & 1 & 0.25 & 0.5 & $\mathbf{0 . 0 3 2}$ \\
Species associated with the seed bank & & & & & & \\
Juncus bufonius & native & monocot & $\mathrm{a}$ & 1 & 0.8 & 0.894 & $\mathbf{0 . 0 0 1}$ \\
Juncus planifolius & native & monocot & $\mathrm{a}$ & 1 & 0.775 & 0.88 & $\mathbf{0 . 0 0 1}$ \\
Juncus procerus & native & monocot & $\mathrm{p}$ & 0.875 & 0.875 & 0.875 & $\mathbf{0 . 0 0 1}$ \\
Juncus articulatus & exotic & monocot & $\mathrm{p}$ & 1 & 0.575 & 0.758 & $\mathbf{0 . 0 0 9}$ \\
Juncus bulbosus & exotic & monocot & $\mathrm{p}$ & 1 & 0.5 & 0.707 & $\mathbf{0 . 0 3 8}$ \\
Gratiola pubescens & native & forb & $\mathrm{p}$ & 1 & 0.475 & 0.689 & $\mathbf{0 . 0 4}$ \\
\hline
\end{tabular}

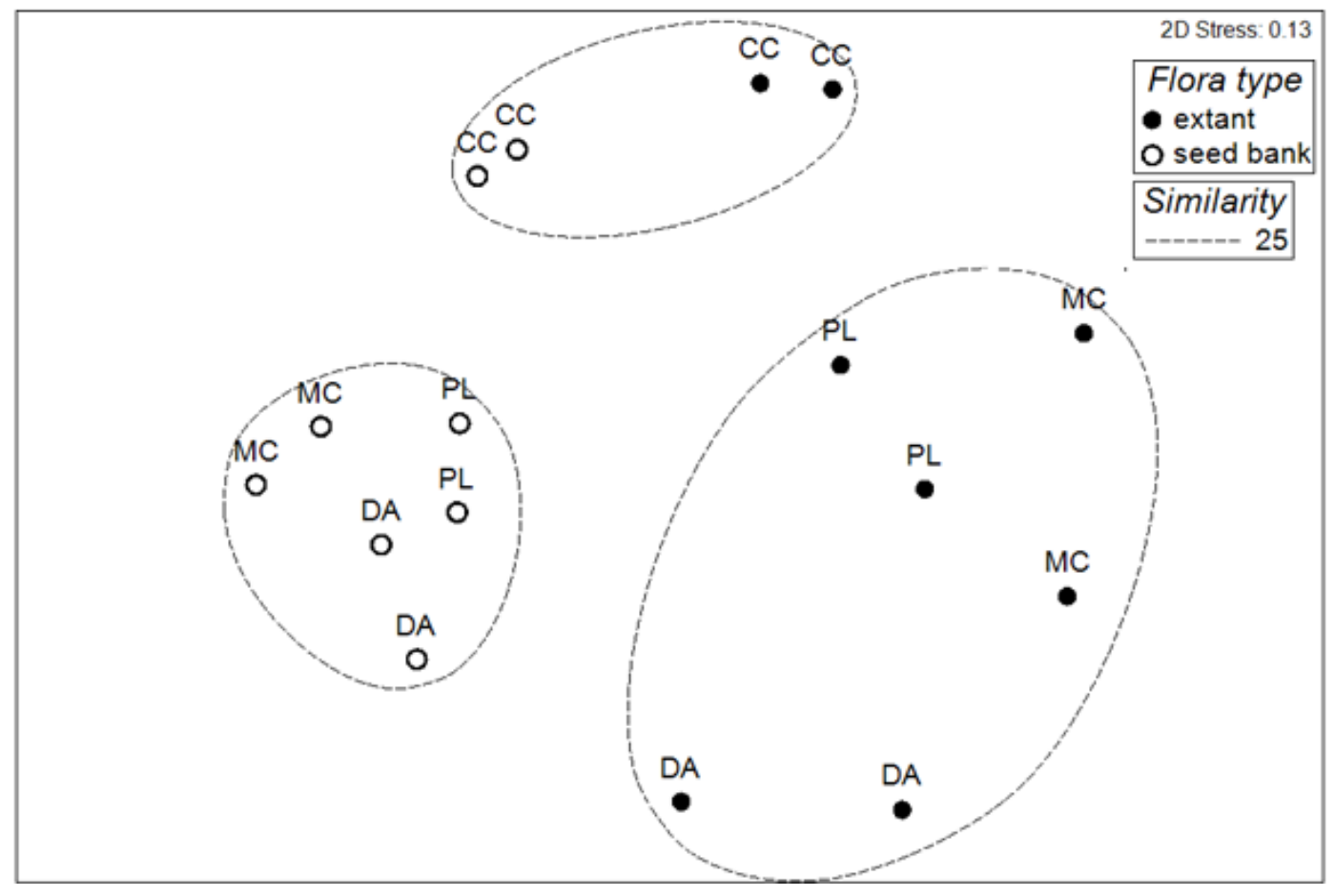

Fig. 2. NMDS ordination of the extant and seed bank floras based on the quadrat survey and seed bank sample data (averaged at the quadrat-level) respectively; labels indicate Site. Dashed ovals represent hierachial cluster groupings at the $25 \%$ similarity level.

\section{Relationship between seed bank composition and extant vegetation condition}

There were significant differences between the seed bank floras of the different sites, with sites with more disturbed understorey vegetation tending to have seed banks with fewer native and more exotic species (Fig. 3). The average cover of exotic understorey species recorded in quadrats at Sites MC (0.5\%) and DA (3\%) was much less than at Sites PL (60\%) and CC (95\%). Correspondingly, native species richness of the seed bank was greatest for one of the less disturbed sites, Site DA, and least for the most disturbed site, Site CC $(p=0.039)$. Conversely, the two most disturbed sites tended to 
have greater exotic species richness $(p=0.096)$ and exotic species seedling abundance $(p=0.049)$. Patterns between overstorey condition and seed bank composition were not apparent.
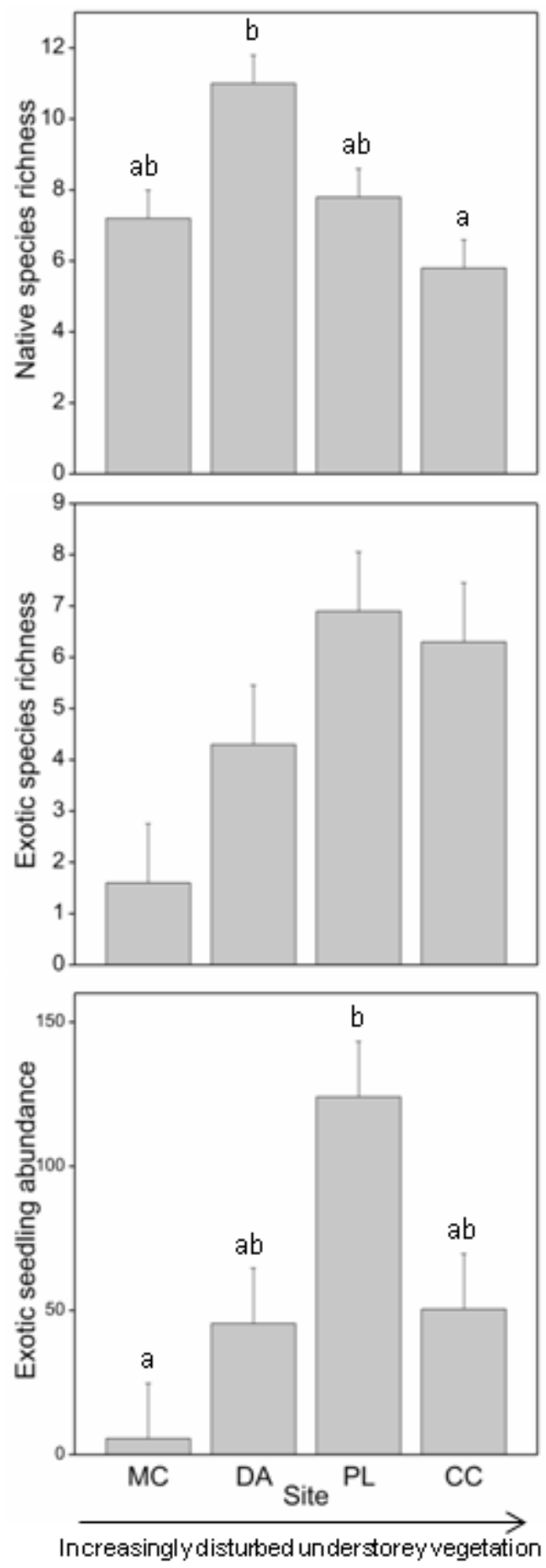

Fig. 3. Associations between seed bank flora composition and sites, with sites shown in order of increasingly disturbed understorey vegetation. Fitted means with standard error bars presented. Significant differences between site means determined by post-hoc Tukey's HSD tests indicated by lower case letters.

\section{Discussion}

Overall, the soil seed bank and extant floras of the wetland forests surveyed were dissimilar. In particular, very few woody plant seedlings or seedlings from the dominant extant species were recovered from the soil seed bank. The soil seed bank did contain a diversity of native herbaceous 
plant species, however, it was largely dominated by a few monocot species, and in some cases contained marked numbers of exotic species-comparatively many more than in the extant vegetation-particularly at disturbed sites.

Soil seed banks tend to be dominated by pioneer species-those adapted to readily colonise disturbed areas (i.e. ruderals sensu Grime 1977). Ruderal species tend to be short-lived, i.e. annual or biennial species, produce large numbers of seeds, and several studies have found wetland seed banks to be dominated by such species (Capon \& Brock 2006; Lu et al. 2010; O'Donnell et al. 2014). However, some studies have found wetland perennials to also be common in the soil seed bank (Richter \& Stromberg 2005; Williams et al. 2008), as was found in this study (e.g. Carex appressa which was common in the extant vegetation was also well represented in the seed bank).

Ruderal species tend to produce large numbers of small seeds that are highly mobile (readily dispersed by wind or water), and many are successful invaders of degraded native vegetation communities (i.e. exotics). Indeed, seed banks often contain considerable numbers of exotics (Williams et al. 2008; O'Donnell et al. 2014). Furthermore, degraded wetland areas are likely to have seed banks with an enhanced prevalence of exotics (Williams et al. 2008; Greet et al. 2012; O'Donnell et al. 2016). Thus, degradation can lead to increased similarity of extant and seed bank floras as both become dominated by weedy vegetation (Gioria \& Osborne 2009). Similar findings were made in the current study, with greater numbers of annual/biennial species, and almost twice as many exotics recorded in the seed bank compared to the extant vegetation. Furthermore, this pattern was more pronounced in more degraded sites, sites at which the similarity of the extant and seed bank floras was greatest.

Many herbaceous perennial wetland plants rely on vegetative reproduction rather than reproduction from seed. Such clonal species - more common in permanently moist than in ephemeral wetland environments - can be expected to be largely absent from the soil seed bank (Abernethy \& Willby 1999; Hopfensperger 2007). Indeed, in this study, clonal species that were dominant in the understorey such as Phragmites australis, Baumea rubiginosa, and Gahnia radula, were absent from the soil seed bank. Together, the lack of woody and clonal species in wetland seed banks accounts for their general lack of similarity with the extant floras of wetland environments (Thompson \& Grime 1979; Boedeltje et al. 2003). This dissimilarity could be expected to be particularly pronounced in wetland forests (i.e. swamps), which are dominated by woody vegetation and tend to be more permanently moist and thus favourable to plants that reproduce vegetatively. However, this dissimilarity could be expected to be reduced following a major disturbance, e.g. flood or fire, when significant germination from the soil seed bank could be expected (Capon \& Brock 2006; Hopfensperger 2007).

The absence of a sizeable woody soil seed bank is typical of wetland environments (Leck \& Graveline 1979; Schneider \& Sharitz 1986; Middleton 2003; Lu et al. 2010). Woody wetland plants often release seeds that are non-dormant (germinate readily) and/or viable for only a short period of time. Thus, rather than a persistent soil seed bank, woody wetland plants depend on other reproductive strategies including: seed release periods timed to coincide with favourable hydrological conditions (Mahoney \& Rood 1998; Pettit \& Froend 2001); vegetative reproduction (e.g. willows; Stokes \& Cunningham 2006); or serotiny-i.e. the storage of seeds in their canopy, seeds which are then released en masse following a significant disturbance such as a flood or fire (Jensen et al. 2008; 
Hamilton-Brown et al. 2009). The dominant tree of the wetland forests studied, E. camphora, exhibits all these traits, i.e.: its seeds germinate readily; it releases a pulse of seeds in late spring/early summer; forms new trees via the epicormic growth of fallen trees; and stores seed in its canopy (Greet 2015). Woody co-dominants such as Melaleuca squarrosa and Leptospermum lanigerum behave similarly. While the soil seed bank was only sampled on one occasion for this study (and at a time not correlated with the peak seed release timing of the woody dominants), a steady background seed rain is observed in seedfall traps, and other soil bank assays at the site have similarly revealed a lack of woody plant propagules (Michelle Faram, pers. comm.).

\section{Role for wetland seed banks in wetland forest restoration?}

Many authors who have found species-rich wetland seed banks have promoted their potential to drive vegetation recovery following the removal of a degrading pressure (e.g. inappropriate water regime or plant invasion), or even their use as a donor seed bank for the restoration of nearby degraded areas (Richter \& Stromberg 2005; Li et al. 2008; Tererai et al. 2015). It is possible that wetland soil seed banks in such situations could contribute to the diversity of understorey vegetation. Indeed, in the wetland forest system we studied, the soil seed bank is likely to contribute to the maintenance of some native herbaceous plant populations (e.g. Carex appressa) and the species richness of the site.

However, wetland seed banks are only likely to be useful for restoring some components of the vegetation community, primarily for supporting early stages of succession via the regeneration of pioneer plants (Leyer 2006; Vosse et al. 2008). The very low similarity recorded between the extant and soil seed bank floras in this study suggests that only a subset of the herbaceous plants surveyed use the seed bank as a mechanism for population maintenance (Hanlon et al 1998). Furthermore, the potential of soil seed banks, particularly in degraded areas, to act as source of exotic plant invasions may hinder rather than help restoration efforts (Williams et al. 2008; O'Donnell et al. 2014).

Our results indicate that soil seed banks are likely to be least useful in the restoration of wetland forests where the dominant plants are woody and clonal. In the absence of large disturbances (i.e. fires or floods, which may provide safe sites for recruitment and trigger the large-scale release of canopy-stored seed and/or promote vegetative reproduction) woody plant propagules may need to be introduced in restoration activities, such as via plantings or direct seeding. Natural regeneration of woody wetland plants is likely to require appropriate water regimes and the presence of mature remnant vegetation as a source of seed (Mahoney \& Rood 1998; O'Donnell et al. 2014). Maintaining (or reconnecting) dispersal pathways (e.g. floodplain connectivity) and intact native vegetation upstream may provide other important potential sources of seed for woody plant regeneration (Middleton 2003; O'Donnell et al. 2016). However, in cases where the restoration of woody vegetation is imperative, e.g. for the maintenance of critical habitat for endangered arboreal fauna, target species will often need to be planted or sown (Boudell \& Stromberg 2008; O'Donnell et al. 2014).

In wetlands, as in other vegetation communities, complementary mechanisms of regeneration are involved in the maintenance of floristic diversity (Thompson \& Grime 1979). Consequently, a mixed approach to the restoration of wetland plant communities is likely to be most successful (Boudell \& Stromberg 2008). Soil seed banks may provide a source of propagules for pioneer vegetation and 
some perennial herbaceous species, thus facilitating vegetation regeneration (O'Donnell et al. 2016). However, for woody plants, their introduction via direct seeding or planting is likely to be necessary in the short-term, with the preservation of remnant vegetation and maintenance of appropriate water regimes and dispersal pathways important for ensuring the ability of wetland forests to selfsustain in the long-term.

\section{Acknowledgements}

Thanks to: Friend of the Helmeted Honeyeater, in particular Michelle Faram of the FoHH nursery; Tony Lovell and Alf McDonald for their assistance in the field; Nick Osborne and Sascha Andrusiak for their help in the nursery; Chandra Jayasuriya for help with Fig. 1; Damien Cook, Dan Robertson and Rob Dabal for help with plant identification; and Justin Trounson, Elizabeth Martin and two anonymous reviewers. This research was funded by Melbourne Water through the Melbourne Waterway Research Practice Partnership.

\section{References}

Abernethy, V.J. \& Willby, N.J. 1999. Changes along a disturbance gradient in the density and composition of propagule banks in floodplain aquatic habitats. Plant Ecology 140: 177-190.

Anderson, M. 2001. A new method for non-parametric multivariate analysis of variance. Austral Ecology 26: 32-46.

Baldwin, A.H., Kettenring, K.M. \& Whigham, D.F. 2010. Seed banks of Phragmites australisdominated brackish wetlands: relationships to seed viability, inundation, and land cover. Aquatic Botany 93: 163-169.

Boedeltje, G., Bakker, J.P. \& ter Heerdt, G.N. 2003. Potential role of propagule banks in the development of aquatic vegetation in backwaters along navigation canals. Aquatic Botany 77: 53-69.

Boudell, J.A. \& Stromberg, J.C. 2008. Propagule banks: potential contribution to restoration of an impounded and dewatered riparian ecosystem. Wetlands 28: 656-665.

Brock, M.A. \& Casanova, M.T. 1997. Plant life at the edge of wetlands: ecological responses to wetting and drying patterns. In: Klomp, N. \& Lunt, I. (eds.) Frontiers in ecology: building the links. Elsevier Science, Oxford, UK.

Brock, M.A., Nielsen, D.L., Shiel, R.J., Green, J.D. \& Langley, J.D. 2003. Drought and aquatic community resilience: the role of eggs and seeds in sediments of temporary wetlands. Freshwater Biology 48: 1207-1218.

Brock, M.A., Theodore, K. \& O'Donnell, L. 1994. Seed-bank methods for Australian wetlands. Australian Journal of Marine and Freshwater Research 45: 483-493.

Capon, S.J. \& Brock, M.A. 2006. Flooding, soil seed bank dynamics and vegetation resilience of a hydrologically variable desert floodplain. Freshwater Biology 51: 206-223.

Casanova, M.T. \& Brock, M.A. 2000. How do depth, duration and frequency of flooding influence the establishment of wetland plant communities? Plant Ecology 147: 237-250.

Clarke, K. \& Gorley, R. 2001. PRIMER v5: user manual/tutorial. PRIMER-E Ltd, Plymouth, UK

De Caceres, M. \& Legendre, P. 2009. Associations between species and groups of sites: indices and statistical inference. Ecology 90: 3566-3574.

Eldridge, D.J. \& Lunt, I.D. 2010. Resilience of soil seed banks to site degradation in intermittently flooded riverine woodlands. Journal of Vegetation Science 21: 157-166.

Gioria, M. \& Osborne, B. 2009. Assessing the impact of plant invasions on soil seed bank communities: use of univariate and multivariate statistical approaches. Journal of Vegetation Science 20: 547-556.

Greet, J. 2015. The marked flooding tolerance of seedlings of a threatened swamp gum: implications for the restoration of critical wetland forests. Australian Journal of Botany 63: 669-678. 
Greet, J., Cousens, R.D. \& Webb, J.A. 2012. Flow regulation is associated with riverine soil seed bank composition within an agricultural landscape: potential implications for restoration Journal of Vegetation Science 24: 157-167.

Grime, J. 1977. Evidence for the existence of three primary strategies in plants and its relevance to ecological and evolutionary theory. American naturalist: 1169-1194.

Gross, K.L. 1990. A comparison of methods for estimating seed numbers in the soil. Journal of Ecology 78: 1079-1093.

Hamilton-Brown, S., Boon, P.I., Raulings, E., Morris, K. \& Robinson, R. 2009. Aerial seed storage in Melaleuca ericifolia Sm. (Swamp Paperbark): environmental triggers for seed release. Hydrobiologia 620: 121-133.

Harley, D.K.P., Worley, M.A. \& Harley, T.K. 2005. The distribution and abundance of Leadbeater's Possum Gymnobelideus leadbeateri in lowland swamp forest at Yellingbo Nature Conservation Reserve. Australian Mammalogy 27: 7-15.

Hopfensperger, K.N. 2007. A review of similarity between seed bank and standing vegetation across ecosystems. Oikos 116: 1438-1448.

James, C.S., Capon, S.J., White, M.G., Rayburg, S.C. \& Thoms, M.C. 2007. Spatial variability of the soil seed bank in a heterogeneous ephemeral wetland system in semi-arid Australia. Plant Ecology 190: 205-217.

Jensen, A.E., Walker, K.F. \& Paton, D.C. 2008. The role of seedbanks in restoration of floodplain woodlands. River Research and Applications 24: 632-649.

Kettenring, K.M. \& Galatowitsch, S.M. 2011. Seed rain of restored and natural prairie wetlands. Wetlands 31: 283-294.

Kruskal, J. \& Wish, M. 1978. Multidimensional Scaling. Sage Publications, Beverley Hills, California, US.

Leck, M.A. \& Graveline, K.J. 1979. Seed bank of a freshwater tidal marsh. American Journal of Botany 66: 1006-1015.

Leyer, I. 2006. Dispersal, diversity and distribution patterns in pioneer vegetation: the role of riverfloodplain connectivity. Journal of Vegetation Science 17: 407-416.

Li, E.-H., Liu, G.-H., Li, W., Yuan, L.-Y. \& Li, S.-C. 2008. The seed-bank of a lakeshore wetland in Lake Honghu: implications for restoration. Plant Ecology 195: 69-76.

Lu, Z.J., Li, L.F., Jiang, M.X., Huang, H.D. \& Bao, D.C. 2010. Can the soil seed bank contribute to revegetation of the drawdown zone in the Three Gorges Reservoir Region? Plant Ecology 209: 153-165.

Mahoney, J.M. \& Rood, S.B. 1998. Streamflow requirements for cottonwood seedling recruitment an integrative model. Wetlands 18: 634-645.

Middleton, B.A. 2003. Soil seed banks and the potential restoration of forested wetlands after farming. Journal of Applied Ecology 40: 1025-1034.

Nishihiro, J., Nishihiro, M.A. \& Washitani, I. 2006. Assessing the potential for recovery of lakeshore vegetation: species richness of sediment propagule banks. Ecological Research 21: 436-445.

O'Donnell, J., Fryirs, K. \& Leishman, M. 2014. Can the regeneration of vegetation from riparian seed bank support biogeomorphic succession and the geomorphic recovery of degraded river chanels? River Research and Applications: DOI: 10.1002/rra.2778.

O'Donnell, J., Fryirs, K.A. \& Leishman, M.R. 2016. Seed banks as a source of vegetation regeneration to support the recovery of degraded rivers: A comparison of river reaches of varying condition. Science of The Total Environment 542: 591-602.

Patterson, H.D. \& Thompson, R. 1971. Recovery of inter-block information when block sizes are unequal. Biometrika 58: 545-554.

Pearce, J. \& Minchin, P.R. 2001. Vegetation of the Yellingbo Nature Conservation Reserve and its relationship to the distribution of the Helmeted Honeyeater, Bell Miner and White-eared Honeyeater. Wildlife Research 28: 41-52. 
Pettit, N.E. \& Froend, R.H. 2001. Availability of seed for recruitment of riparian vegetation: a comparison of a tropical and a temperate river ecosystem in Australia. Australian Journal of Botany 49: 515-528.

Poiani, K.A. \& Johnson, W.C. 1988. Evaluation of the emergence method in estimating seed bank composition of prairie wetlands. Aquatic Botany 32: 91-97.

Richter, R. \& Stromberg, J.C. 2005. Soil seed banks of two montane riparian areas: implications for restoration. Biodiversity and Conservation 14: 993-1016.

Schneider, R.L. \& Sharitz, R.R. 1986. Seed bank dynamics in a southeastern riverine swamp. American Journal of Botany 73: 1022-1030.

Stokes, K.E. \& Cunningham, S.A. 2006. Predictors of recruitment for willows invading riparian environments in south-east Australia: implications for weed management. Journal of Applied Ecology 43: 909-921.

Tererai, F., Gaertner, M., Jacobs, S.M. \& Richardson, D.M. 2015. Resilience of invaded riparian landscapes: the potential role of soil-stored seed banks. Environmental Management 55: 8699.

Thompson, K. \& Grime, J.P. 1979. Seasonal-variation in the seed banks of herbaceous species in 10 contrasting habitats. Journal of Ecology 67: 893-921.

Turner, V. 2003. Action Statement: Sedge-rich Eucalyptus camphora Swamp. Report to the Department of Sustainability and Environment. Aurthur Rylah Institute. In.

van der Valk, A.G. \& Davis, C.B. 1978. Role of seed banks in vegetation dynamics of prairie glacial marshes. Ecology 59: 322-335.

Vosse, S., Esler, K.J., Richardson, D.M. \& Holmes, P.M. 2008. Can riparian seed banks initiate restoration after alien plant invasion? Evidence from the Western Cape, South Africa. South African Journal of Botany 74: 432-444.

Williams, L., Reich, P., Capon, S.J. \& Raulings, E. 2008. Soil seed banks of degraded riparian zones in southeastern Australia and their potential contribution to the restoration of understorey vegetation. River Research and Applications 24: 1002-1017. 


\section{Appendix 1}

List of species surveyed across all four sites listed in order of decreasing frequency of occurrence. Species characteristics presented: origin (native or exotic); growth form (rush, sedge, grass, forb, tree/shrub), and life-span (a annual/biennial; $p$ - perennial). Occurrences $=$ no. of quadrats (out of eight) in which that species was observed. Mean cover $=$ average cover of that species across all surveyed quadrats.

\begin{tabular}{|c|c|c|c|c|c|}
\hline Scientific Name & Origin & $\begin{array}{l}\text { Growth } \\
\text { form }\end{array}$ & $\begin{array}{l}\text { Life- } \\
\text { span }\end{array}$ & Occurrences & $\begin{array}{l}\text { Mean cover } \\
\text { (\%) }\end{array}$ \\
\hline \multicolumn{6}{|l|}{ Eucalyptus camphora subsp. } \\
\hline humeana & native & tree/shrub & $p$ & 7 & 36 \\
\hline Carex appressa & native & sedge & $p$ & 7 & 14 \\
\hline Phragmites australis & native & grass & $p$ & 5 & 8 \\
\hline Baumea rubiginosa & native & sedge & $p$ & 4 & 14 \\
\hline Melaleuca squarrosa & native & tree/shrub & $\mathrm{p}$ & 4 & 12 \\
\hline Senecio minimus & native & forb & a & 4 & 3 \\
\hline Centella cordifolia & native & forb & $p$ & 4 & 1 \\
\hline Acacia melanoxylon & native & tree/shrub & $p$ & 3 & 10 \\
\hline Tetrarrhena juncea & native & grass & $p$ & 3 & 6 \\
\hline Gahnia radula & native & sedge & $p$ & 3 & 4 \\
\hline Rubus anglocandicans & exotic & tree/shrub & $p$ & 3 & 3 \\
\hline Leptospermum lanigerum & native & tree/shrub & $p$ & 3 & 3 \\
\hline Gonocarpus humilis & native & forb & $p$ & 3 & 2 \\
\hline Galium aparine & exotic & forb & a & 3 & 2 \\
\hline Persicaria praetermissa & native & forb & $\mathrm{p}$ & 3 & 1 \\
\hline Schoenus lepidosperma & native & sedge & $p$ & 3 & 1 \\
\hline Austrocynoglossum latifolium & native & forb & $p$ & 3 & 1 \\
\hline Prunella vulgaris & exotic & forb & $p$ & 3 & 1 \\
\hline Lotus corniculatus & exotic & forb & $\mathrm{p}$ & 3 & 1 \\
\hline Hypochaeris radicata & exotic & forb & $\mathrm{p}$ & 3 & 0 \\
\hline Anthoxanthum odoratum & exotic & grass & $p$ & 2 & 14 \\
\hline Ranunculus repens & exotic & forb & $p$ & 2 & 11 \\
\hline Holcus lanatus & exotic & grass & $p$ & 2 & 4 \\
\hline Baloskion tetraphyllum & native & restio & $p$ & 2 & 3 \\
\hline Coprosma quadrifida & native & tree/shrub & $p$ & 2 & 3 \\
\hline Triglochin procera & native & forb & $p$ & 2 & 1 \\
\hline Ranunculus inundatus & native & forb & $p$ & 2 & 1 \\
\hline Cardamine hirsuta & exotic & forb & $a$ & 2 & 1 \\
\hline Baumea tetragona & native & sedge & $p$ & 1 & 2 \\
\hline Lomandra longifolia & native & rush & $\mathrm{p}$ & 1 & 2 \\
\hline Melaleuca ericifolia & native & tree/shrub & $\mathrm{p}$ & 1 & 2 \\
\hline Leptospermum scoparium & native & tree/shrub & $p$ & 1 & 1 \\
\hline Banksia marginata & native & tree/shrub & $p$ & 1 & 1 \\
\hline Pteridium esculentum & native & fern & $p$ & 1 & 1 \\
\hline Potentilla indica & exotic & forb & $p$ & 1 & 1 \\
\hline Poa annua & exotic & grass & $a$ & 1 & 1 \\
\hline Dianella tasmanica & native & xan & $\mathrm{p}$ & 1 & 1 \\
\hline Xanthorrhoea minor & native & xan & $p$ & 1 & 1 \\
\hline Cirsium vulgare & exotic & forb & a & 1 & 1 \\
\hline Persicaria subsessilis & native & forb & $p$ & 1 & 1 \\
\hline Poa tenera & native & grass & $p$ & 1 & 1 \\
\hline Callitriche stagnalis & exotic & forb & $a / p$ & 1 & $<1$ \\
\hline Isolepis inundata & native & sedge & $p$ & 1 & $<1$ \\
\hline
\end{tabular}




\begin{tabular}{llllll}
\hline Juncus procerus & native & rush & $\mathrm{p}$ & 1 & $<1$ \\
Austrostipa sp. & native & grass & $\mathrm{p}$ & 1 & $<1$ \\
Solanum nigrum & exotic & forb & $\mathrm{a}$ & 1 & $<1$ \\
Acaena novae-zelandiae & native & forb & $\mathrm{p}$ & 1 & $<1$ \\
Juncus sarophorus & native & rush & $\mathrm{p}$ & 1 & $<1$ \\
Lobelia anceps & native & forb & $\mathrm{p}$ & 1 & $<1$ \\
Rumex conglomeratus & exotic & forb & $\mathrm{a}$ & 1 & $<1$ \\
Mentha australis & native & forb & $\mathrm{p}$ & 1 & $<1$ \\
Lomandra filiformis & native & rush & $\mathrm{p}$ & 1 & $<1$ \\
Euchiton involucratus & native & forb & $\mathrm{a}$ & 1 & $<1$ \\
Juncus prismatocarpus & native & rush & $\mathrm{p}$ & 1 & $<1$ \\
Trifolium repens & exotic & forb & $\mathrm{p}$ & 1 & $<1$ \\
Hypochaeris glabra & exotic & forb & $\mathrm{a}$ & 1 & $<1$ \\
Urtica urens & exotic & forb & $\mathrm{a}$ & 1 & $<1$ \\
\hline
\end{tabular}




\section{Appendix 2}

List of seed bank taxa listed in order of decreasing density. Taxa characteristics presented: origin (native or exotic); growth form (rush, sedge, grass, forb, tree/shrub), and life-span (a - annual/biennial; $p$ - perennial). Total nos. of seedlings $=$ total numbers of seedlings of that taxa that emerged from all collected samples $(n=40)$. Mean density $=$ the average density of seedlings $/ \mathrm{m}^{2}$ of topsoil (top $5 \mathrm{~cm}$ of soil) for that taxa across all samples collected.

\begin{tabular}{|c|c|c|c|c|c|}
\hline Scientific Name & Origin & $\begin{array}{l}\text { Growth } \\
\text { form }\end{array}$ & $\begin{array}{l}\text { Life- } \\
\text { span }\end{array}$ & $\begin{array}{l}\text { Total nos. of } \\
\text { seedlings }\end{array}$ & $\begin{array}{l}\text { Mean density } \\
\left(\text { seedlings } / \mathbf{m}^{2}\right)\end{array}$ \\
\hline Juncus bufonius & native & rush & $\bar{a}$ & 963 & 2452.26 \\
\hline Juncus bulbosus & exotic & rush & $\mathrm{p}$ & 742 & 1889.49 \\
\hline Juncus articulatus & exotic & rush & $p$ & 666 & 1695.96 \\
\hline Juncus planifolius & native & rush & a & 647 & 1647.57 \\
\hline Isolepis inundata & native & sedge & $\mathrm{p}$ & 523 & 1331.81 \\
\hline Juncus procerus & native & rush & $p$ & 492 & 1252.87 \\
\hline Senecio minimus & native & forb & a & 418 & 1064.43 \\
\hline Gratiola pubescens & native & forb & $\mathrm{p}$ & 287 & 730.84 \\
\hline Carex appressa & native & sedge & $p$ & 211 & 537.31 \\
\hline Cardamine hirsuta & exotic & forb & a & 149 & 379.43 \\
\hline Ranunculus repens & exotic & forb & $\mathrm{p}$ & 143 & 364.15 \\
\hline Lobelia anceps & native & forb & $\mathrm{p}$ & 122 & 310.67 \\
\hline Anthoxanthum odoratum & exotic & grass & $\mathrm{p}$ & 121 & 308.12 \\
\hline Baloskion tetraphyllum & native & rush & $\mathrm{p}$ & 117 & 297.94 \\
\hline Holcus lanatus & exotic & grass & $\mathrm{p}$ & 98 & 249.55 \\
\hline Centella cordifolia & native & forb & $\mathrm{p}$ & 80 & 203.72 \\
\hline Austrocynoglossum latifolium & native & forb & $\mathrm{p}$ & 45 & 114.59 \\
\hline Centrolepis fascicularis & native & sedge & $\mathrm{p}$ & 43 & 109.50 \\
\hline Lotus corniculatus & exotic & forb & $\mathrm{p}$ & 43 & 109.50 \\
\hline Callitriche stagnalis & exotic & forb & a & 41 & 104.41 \\
\hline unknown grass sp. 1 & unknown & grass & & 36 & 91.67 \\
\hline Juncus capitatus & exotic & rush & a & 33 & 84.03 \\
\hline Lolium perenne & exotic & grass & $\mathrm{p}$ & 33 & 84.03 \\
\hline Solanum nigrum & exotic & forb & a & 30 & 76.39 \\
\hline Isolepis levynsiana & exotic & sedge & a & 20 & 50.93 \\
\hline Sisyrinchium iridifolium & exotic & forb & a & 19 & 48.38 \\
\hline Gonocarpus micranthus & native & forb & $\mathrm{p}$ & 18 & 45.84 \\
\hline Stellaria media & exotic & forb & a & 18 & 45.84 \\
\hline Trifolium dubium & exotic & forb & a & 16 & 40.74 \\
\hline Cirsium vulgare & exotic & forb & a & 15 & 38.20 \\
\hline Hypericum gramineum & native & forb & $\mathrm{p}$ & 14 & 35.65 \\
\hline Phalaris arundinacea & exotic & grass & $\mathrm{p}$ & 12 & 30.56 \\
\hline Juncus prismatocarpus & native & rush & $\mathrm{p}$ & 11 & 28.01 \\
\hline Kunzea ericoides & native & tree/shrub & $p$ & 10 & 25.46 \\
\hline Cardamine tenuifolia & native & forb & $\mathrm{p}$ & 9 & 22.92 \\
\hline Centaurium tenuiflorum & exotic & forb & a & 7 & 17.83 \\
\hline Leptospermum lanigerum & native & tree/shrub & $\mathrm{p}$ & 6 & 15.28 \\
\hline Rubus anglocandicans & exotic & tree/shrub & $\mathrm{p}$ & 6 & 15.28 \\
\hline Typha latifolia & exotic & typha & $\mathrm{p}$ & 6 & 15.28 \\
\hline Cerastium glomeratum & exotic & forb & a & 5 & 12.73 \\
\hline Hypochaeris radicata & exotic & forb & $\mathrm{p}$ & 5 & 12.73 \\
\hline Myriophyllum pedunculatum & native & forb & $\mathrm{p}$ & 5 & 12.73 \\
\hline Poa tenera & native & grass & $\mathrm{p}$ & 5 & 12.73 \\
\hline Acacia melanoxylon & native & tree/shrub & $\mathrm{p}$ & 4 & 10.19 \\
\hline
\end{tabular}




\begin{tabular}{|c|c|c|c|c|c|}
\hline Banksia spinulosa & native & tree/shrub & $p$ & 4 & 10.19 \\
\hline Eleocharis gracilis & native & sedge & $\mathrm{p}$ & 4 & 10.19 \\
\hline Eragrostis brownii & native & grass & $p$ & 4 & 10.19 \\
\hline Euchiton involucratus & native & forb & a & 4 & 10.19 \\
\hline Gonocarpus humilis & native & forb & $p$ & 4 & 10.19 \\
\hline Lomandra filiformis & native & rush & $p$ & 4 & 10.19 \\
\hline Lotus uliginosus & exotic & forb & $p$ & 4 & 10.19 \\
\hline Lycopus australis & native & forb & $p$ & 4 & 10.19 \\
\hline Trifolium glomeratum & exotic & forb & a & 4 & 10.19 \\
\hline Urtica urens & exotic & forb & a & 4 & 10.19 \\
\hline Isolepis cernua & native & sedge & $\mathrm{p}$ & 3 & 7.64 \\
\hline Ranunculus amphitrichus & native & forb & $p$ & 3 & 7.64 \\
\hline Ranunculus flammula & exotic & forb & $p$ & 3 & 7.64 \\
\hline Rumex conglomeratus & exotic & forb & a & 3 & 7.64 \\
\hline Acaena novae-zelandiae & native & forb & $\mathrm{p}$ & 2 & 5.09 \\
\hline Baumea tetragona & native & sedge & $p$ & 2 & 5.09 \\
\hline Cassinia arcuata & native & tree/shrub & $p$ & 2 & 5.09 \\
\hline Centripeda cunninghamii & native & forb & $p$ & 2 & 5.09 \\
\hline Centrolepis strigosa & native & sedge & a & 2 & 5.09 \\
\hline Dianella tasmanica & native & xan & $\mathrm{p}$ & 2 & 5.09 \\
\hline unknown grass sp. 2 & unknown & grass & & 2 & 5.09 \\
\hline Galium aparine & exotic & forb & a & 2 & 5.09 \\
\hline Helichrysum luteoalbum & native & forb & a & 2 & 5.09 \\
\hline Hydrocotyle pterocarpa & native & forb & $p$ & 2 & 5.09 \\
\hline Ozothamnus ferrugineus & native & tree/shrub & $p$ & 2 & 5.09 \\
\hline Prunella vulgaris & exotic & forb & $\mathrm{p}$ & 2 & 5.09 \\
\hline Sagina procumbens & exotic & forb & $p$ & 2 & 5.09 \\
\hline Sonchus oleraceus & exotic & forb & a & 2 & 5.09 \\
\hline Trifolium repens & exotic & forb & $\mathrm{p}$ & 2 & 5.09 \\
\hline Caesia parviflora & native & sedge & $p$ & 1 & 2.55 \\
\hline Carex fascicularis & native & sedge & $p$ & 1 & 2.55 \\
\hline Centrolepis aristrata & native & sedge & a & 1 & 2.55 \\
\hline Conyza bonariensis & exotic & forb & a & 1 & 2.55 \\
\hline Drosera peltata & native & forb & $\mathrm{p}$ & 1 & 2.55 \\
\hline Gratiola peruviana & native & forb & $p$ & 1 & 2.55 \\
\hline Lepyrodia muelleri & native & forb & $p$ & 1 & 2.55 \\
\hline
\end{tabular}




\section{University Library}

\section{- M M N E R VA A gateway to Melbourne's research publications}

Minerva Access is the Institutional Repository of The University of Melbourne

Author/s:

Greet, J

Title:

The potential of soil seed banks of a eucalypt wetland forest to aid restoration

Date:

2016-10-01

Citation:

Greet, J. (2016). The potential of soil seed banks of a eucalypt wetland forest to aid restoration. WETLANDS ECOLOGY AND MANAGEMENT, 24 (5), pp.565-577. https:// doi.org/10.1007/s11273-016-9488-9.

Persistent Link:

http://hdl.handle.net/11343/282603 